\title{
A comparative study of family decision making in US and Turkish households by correspondence analysis
}

\author{
RECEIVED (IN REVISED FORM): II DECEMBER, 2000 \\ Erdener Kaynak and Orsay Kucukemiroglu \\ School of Business Administration, Penn State Harrisburg, Middletown, Pennsylvania \\ 17057, USA \\ Tel: + I (7I7) 948-6343; Fax: + I (7I7) 948-6456; e-mail: K9X@PSU.EDU
}

\begin{abstract}
Cross-cultural, cross-national consumer behaviour is becoming an increasingly relevant area of research as more industries and countries get in on the globalisation trend. In a globalising consumer market, decision making has become more complex and even more important for consumers than in the past. This experimental study presents cross-cultural comparisons of husband and wife decision-making roles in the purchase of a variety of goods and services in unlike environments. The findings show that the dominance of the husband is stronger in Turkey than in the USA. Despite substantial cultural differences, there are surprisingly high degrees of similarity in family purchasing decision roles between the two countries. Managerial and public policy implications of cross-cultural differences in consumer decision making are illustrated and appropriate marketing strategies and policies are offered for orderly decision-making purposes.
\end{abstract}

\section{INTRODUCTION}

As the primary consumer decisionmaking unit, the family has long intrigued the minds of many consumer researchers and behavioural scientists. Several studies have been conducted in the area of husband and wife decisionmaking roles in the purchase of a variety of goods and services. ${ }^{1-8}$ For instance, psychologists are concerned with the roles played by spouses in decision making and the dependence of these roles on various sociopsychological factors. ${ }^{9}$ Market researchers and economists are interested in studying household decision making because information about family decision making may be helpful in predicting consumer intentions, consumer product/service choice and purchase. ${ }^{10}$

Consumer behaviourists conducted comprehensive meta-analyses of the past consumer behaviour literature on country of origin (COO) effects. In particular, they examined the relative impact of $\mathrm{COO}$ on different stages of the consumers' decision-making process such as perception, attitude and behavioural intention. ${ }^{11-13}$ In addition, since the major findings by Davis, ${ }^{14}$ consumer researchers have continued to
Erdener Kaynak is a professor of marketing at the School of Business Administration of Pennsylvania State University at Harrisburg. He has extensive teaching research, consulting and advising experiences in five continents.

Orsay Kucukemiroglu is a professor of business administration and coordinator of the business programmes at Pennsylvania State University at York. 
explore dimensions of family purchasing behaviour, albeit from different perspectives and research angles. ${ }^{15-17}$ Furthermore, Sproles ${ }^{18}$ and Sproles and Kendall ${ }^{19}$ were instrumental in developing and testing a Consumer Styles Inventory (CSI), which pointed a new direction in decision-making research. Studies also indicate that consumers have a particular learning style that uses systematic and careful market search, observation and learning. The learning styles of noveltyand fashion-conscious consumers are similar to those who are perfectionists, with the exception that the noveltyconscious consumer is likely to be a passive learner. ${ }^{20}$ Characteristics of decision-making styles can be useful in profiling an individual consumer style in targeting a select consumer group for marketing planning purposes.

In the current marketing literature, consumer purchase behaviour is examined from three perspectives: the decision making, the experiential and the behavioural influence. In the first instance, consumers engage in problem-solving tasks, in which they move through successive stages. The experimental perspective maintains that consumers make purchases in order to create feelings, experiences and emotions rather than to solve problems. ${ }^{21}$ The behavioural influence approach proposes that consumers, in most cases, act in response to environmental pressures. These perspectives are complementary, focusing on different aspects of the buying and consumption process. ${ }^{22}$

\section{CONSUMER DECISION-MAKING STYLES}

Past consumer behaviour and psychology literature has identified different types of consumer decisionmaking styles. Among all, decisionmaking styles have been identified as being utilised by quality seekers, novelty/fashion seekers, comparison shoppers, information seekers, brand loyal and habitual consumers. In recent years, increases in the number and variety of goods and services, store types, shopping malls and availability of alternate methods of distribution and shopping such as electronic and catalogue shopping have broadened the sphere for consumer choice and selection and have complicated the consumer decision-making process substantially. ${ }^{23}$

In a cross-cultural study conducted by McDonald, ${ }^{24}$ consumers described their decision-making processes to identify distinctive verbal patterns that vary by cultural background. The findings showed that the American consumers acknowledged more emotional influences on their decision making, while the Japanese consumers preferred rational and cognitive explanations. An empirical study conducted by Hafstrom identified decision-making styles of young consumers in the Republic of Korea and in the USA. ${ }^{25}$ The results indicated the generality of some consumer decision-making styles. An eight-factor solution produced the following decision-making styles: brand-consciousness; perfectionist/high-quality 
conscious consuming; recreationalshopping; confusion over choice; time/energy conservation; impulsive, careless shopping; brand-loyal shopping; and price/value consciousness. It was interesting to find out that only the 'novelty/fashion conscious consumer' style identified in previous US studies was not confirmed in the Korean data. In another study, the dimensions and profiles of consumer decision-making styles of young adult Chinese consumers were investigated by using a modified model of consumer decision-making styles. Study results were compared with similar studies using US and Korean data. It was discovered that the dimensions of consumer decisionmaking styles were similar in the three countries. Differences detected in consumer purchasing power and maturity of the consumer market might contribute to the apparent differences in consumer decisionmaking styles. ${ }^{26}$

Past studies investigating consumer decision making have implicitly assumed that one individual in a family, most often the wife, makes all the consumption choices for the family. ${ }^{27}$ Despite this general contention, one observes cross-cultural and/or national differences among consumers in global markets. In another study, husband and wife perceptions of their marital roles in the purchase of several consumer products were presented. It was discovered that the husband had the stronger influence in Ireland on the car, television and lawn mower purchases. The wife's influence was stronger for the three-piece suite and the washing machine purchases. A very high level of joint decision making was found for the mortgage choice. ${ }^{28}$ Information about the roles played by the spouse throughout the decisionmaking process is, however, relevant in assessing the feasibility of marital roles in addition to sex roles as a basis for market segmentation. This type of information is also beneficial to any organisation interested in communicating with appropriate decision maker(s) in the family or obtaining valid data about household choices, preferences, intentions or behaviour. In other words, to maximise the effectiveness of limited household budget allocations, the marketing managers must know which spouse in the household has the dominant influence in decision making so that the marketing and promotional strategy can be tailored or oriented accordingly. ${ }^{29}$ International marketers and public policy makers should also recognise those variations in family purchasing roles which may exist in overseas markets - particularly in markets which possess vastly different social and economic conditions than their own home markets. These people may find it necessary to market their products to market segments that differ substantially from those to which they are accustomed. ${ }^{30}$

In spite of the ongoing interest among researchers and public policy makers regarding the family decision making, most of the studies continue to focus on theory-laden, self-reports 
of spouses living in industrialised countries. Very little research work, so far, has dealt with cross-cultural and cross-national perspective or those of comparative studies. It is true that there are some family-purchasing studies conducted on samples outside the USA. ${ }^{31-34}$ Except for the study conducted by Green et al., ${ }^{35}$ the scope of these studies has been too limited to permit placement of the knowledge regarding family purchasing behaviour into a cross-cultural/national context. For example, Davis and Rigaux reported the results of a research conducted in Belgium. They did not, however, compare their findings with the similar data collected in the USA. Despite this, their findings were similar to the findings of other studies in the USA and elsewhere. ${ }^{36}$ As well, familypurchasing behaviour in developing countries has received very little attention except in the studies conducted by Green et al. ${ }^{37}$ and Yavas et al. ${ }^{38}$ In view of the existing void in the current international marketing literature, this paper looks into the similarities and differences of family decision-making roles in purchasing a variety of consumer goods and services in the USA (a low context culture) and in the advanced developing country of Turkey (a high context culture).

\section{METHODOLOGY}

The data for this study were collected through self-administered questionnaires from Istanbul, Turkey during the winter of 1995 and South Central
Pennsylvania during 1996. Istanbul is the largest and the most cosmopolitan city in Turkey with a sizeable percentage of its population making their living from service industries, light manufacturing and resource-based industries. The choice of this particular city was made on the belief that people who live in a big city are more habituated toward questionnaires, and would respond to surveys more favourably. This situation had an impact on the selection decision. Every effort was made to get a representative cross-section of the population. Nine different parts of Istanbul were selected for the administration of this survey, namely: Aksaray, Bakirköy, Beşiktaş, Beyazit, Fatih, Kadiköy, Karaköy and Taksim where shopping centres are located and population density is high compared to other boroughs of Istanbul. Respondents were randomly intercepted along the streets of the chosen boroughs and contacted personally with the help of senior students from local higher education institutions. A total of 532 usable questionnaires were completed. For the USA data, the survey was conducted in the tri-county region of South Central Pennsylvania. Within this region of the Commonwealth of Pennsylvania, three major cities, Harrisburg, Lancaster and York, were selected as the base for sampling the population. A stratified sampling method was utilised. In terms of economic well being of residents, similar to sample selection in Istanbul, two types of neighbourhoods, namely, upper income and middle income, 
were identified in each city. A total of 200 persons in each city were contacted. The drop-off and pick-up method was used and questionnaires were hand delivered to the houses of the pre-selected households by business administration students of a local university. After a week's waiting period, questionnaires were personally retrieved. Of the 600 households contacted, 403 responses were received and 18 questionnaires, though filled in, were not usable due to incompleteness and response errors. The final analysis was based on 385 completed questionnaires, which gave a response rate of 64 per cent.

A questionnaire for the study was developed in the English language first then translated into Turkish by a bilingual associate. Back translation was also done to check any inconsistency as well as possible translation errors. Before the survey administration, pre-test of the questionnaire with a small group of respondents was conducted, and the results were satisfactory. The questionnaire consisted of five sections. In the first section, 56 activities, interest and opinions (AIO) statements obtained from marketing literature were used to identify lifestyles of Turkish consumers. ${ }^{39-42}$ A five-point Likert scale was used, ' 1 ' being 'strongly disagree' and '5' being 'strongly agree.' The second section of the questionnaire contained questions regarding the household decision-making process. The types of questions used in the instrument were very similar to those incorporated by Davis and Rigaux. ${ }^{43}$ Each respondent was instructed to indicate the primary decision maker in the family (husband, wife or the husband and wife jointly) in regards to: (1) when they bought, (2) where they bought, (3) what they bought, and (4) how much they paid for the purchases of seven selected products and services. These were groceries, major appliances, furniture, automobiles, savings, vacations and life insurance. The third section of the questionnaire consisted of questions about ethnocentrism. Consumer ethnocentrism was measured by the popular CETSCALE developed by Shimp and Sharma. ${ }^{44}$ In the fourth section of the questionnaire, using a five-point Likert scale, perceptions of foreign countries' products were measured. The last section of the questionnaire included demographic and socioeconomic questions, which are used to interpret the responses on other questions. Table 1 shows demographic and socioeconomic characteristics of the survey data.

Before moving on to the interpretation of the survey data, a few points about the collection of the data need to be clarified. In cross-cultural research, two samples had to be as closely matched as possible in terms of the more important demographic characteristics. ${ }^{45,46}$ This is usually very hard to accomplish, especially in the case where two countries do not have directly similar living standards, income or educational systems. Thus in this study, every effort was made 


\section{Table 1}

\section{DEMOGRAPHIC AND SOCIOECONOMIC CHARACTERISTICS OF RESPONDENTS}

\begin{tabular}{|c|c|c|}
\hline Characteristics & Frequencies for Turkey & Frequencies for USA \\
\hline \multicolumn{3}{|l|}{ Age } \\
\hline Below 20 & $37(7 \%)$ & $46(11.9 \%)$ \\
\hline $20-30$ & $188(35.3 \%)$ & $144(37.5 \%)$ \\
\hline $31-40$ & $136(25.5 \%)$ & 87 (22.6\%) \\
\hline $41-50$ & $93(17.5 \%)$ & $65(16.9 \%)$ \\
\hline Over 50 & $78(14.7 \%)$ & $43(11.1 \%)$ \\
\hline Total & $532(100 \%)$ & $385(100 \%)$ \\
\hline \multicolumn{3}{|l|}{ Income $^{a}$} \\
\hline$\$ 500$ or less & $54(10.2 \%)$ & $1(0 \%)$ \\
\hline $501-1,000$ & 203 (38.1\%) & $15(3.4 \%)$ \\
\hline $1,001-2,000$ & $164(30.8 \%)$ & $127(33 \%)$ \\
\hline Over 2,000 & $111(20.9 \%)$ & $242(62.8 \%)$ \\
\hline Total & $532(100 \%)$ & $385(100 \%)$ \\
\hline \multicolumn{3}{|l|}{ Marital status } \\
\hline Single & $109(20.5 \%)$ & $123(31.9 \%)$ \\
\hline Married & $423(79.5 \%)$ & $262(68.1 \%)$ \\
\hline Total & $532(100 \%)$ & $385(100 \%)$ \\
\hline \multicolumn{3}{|l|}{ Gender } \\
\hline Male & $215(40.4 \%)$ & $167(43.3 \%)$ \\
\hline Female & $317(59.6 \%)$ & $218(56.7 \%)$ \\
\hline Total & $532(100 \%)$ & $385(100 \%)$ \\
\hline \multicolumn{3}{|l|}{ Education } \\
\hline Less than high school & $95(17.9 \%)$ & $56(14.5 \%)$ \\
\hline High school & $212(39.8 \%)$ & $82(21.3 \%)$ \\
\hline Some college & $117(22 \%)$ & $162(42.2 \%)$ \\
\hline College & $108(20.3 \%)$ & $85(22 \%)$ \\
\hline Total & $532(100 \%)$ & $385(100 \%)$ \\
\hline
\end{tabular}

${ }^{a}$ Monthly income in Turkish currency (\$US $1=60,000$ T.L.) 
to match the samples on several demographic characteristics: sex, marital status and social class. But as to income and education, due to differences between the two countries, two samples may not be suitable for comparison. Secondly, the findings should not be generalised to the entire population of the USA or of Turkey, because the samples were drawn from only the middle and upper socioeconomic groups of the two countries. Thirdly, the data were collected on only a limited number of products and services, and these products and services may not be functionally equivalent. Therefore, the findings should not be generalised to decision making for all groups of goods and services. Fourthly, only the responses of the wives were recorded; thus the findings represent only the perception of this group of respondents.

\section{FINDINGS}

Correspondence Analysis (CA) was used to analyse the decision-making process as to purchasing within the context of the American and Turkish households. CA is an exploratory multivariate technique that converts frequency tables into graphical displays in which rows and columns are depicted as points. A map of these points can then be constructed so that the higher proportions associated with the various levels of rows and columns are close together on the map. It provides a method for comparing row and column proportions in a twoway or multivariate table. Mathematically, CA decomposes the chi-square measure of association of the table into components in a manner similar to that of principal component analysis for continuous data. ${ }^{47,48}$ The dimensions identified in CA can be interpreted by pinpointing the largest relative contributor to the variance explained by the axis. As with principal components, CA will explain most of the variation if only a few dimensions have strong dichotomies.

The family decision-making responses, namely, husband, wife, or joint for four types of purchase decisions (what to buy, when to buy where to buy and how much to buy); by product category (groceries, automobiles, insurance, vacation, savings, appliances and furniture); by country (USA and Turkey) were used as input data. This conceptualisation effort produced a $7 \times 4 \times 2$ matrix where there are 56 separate possible decisions involving seven product categories, four types of purchasing decisions and two countries (see Figure 1). Since there were more than two sets of nominal data, namely ( d e c is i o n - m a k e r ${ }^{\star}$ product category ${ }^{\star}$ countries), first, three nominal variables were reduced to a binary table in order to examine various relationships by creating rectangular table [(product categories ${ }^{\star}$ countries $){ }^{\star}$ decision-maker]. Figure 2 shows the result of the correspondence analysis for the grand mean profiles for the products as a 
Figure 1: Conceptualising of decision-making process

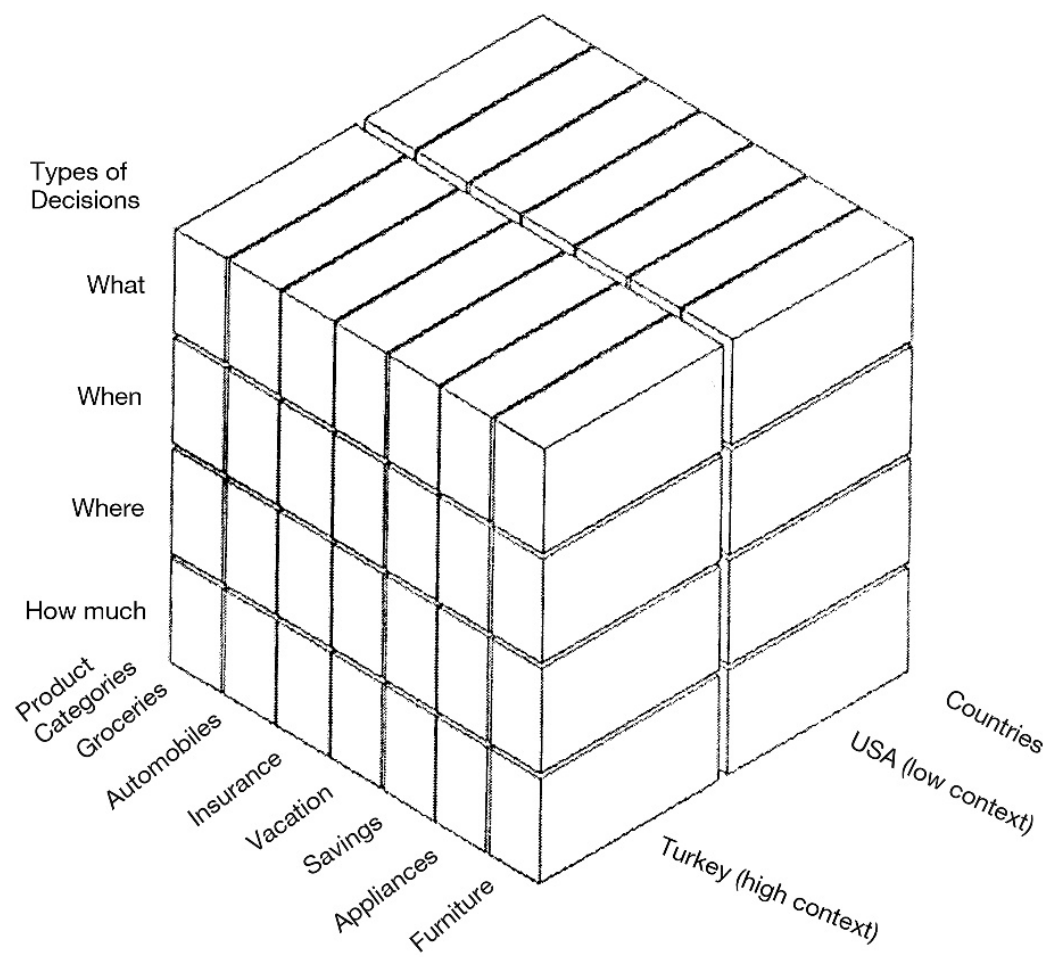

whole instead of individual decisions as to each product category (what, when, where and how much). Findings regarding individual decisions as to each product categories are shown in Figures 3 to 6 , respectively.

The horizontal axis represents the husband dominant/wife dominant dimensions of the relationship. The cluster of points found on the left-hand side of the graph indicates that decisions are predominantly made by the husbands, while those points at the opposite end of the graph show decisions are mostly made by the wives. This axis explains 57.3 per cent of the total variance. As may be seen from the graph, while grocery purchases seem to be a wife-dominant decision area, automobiles are a husband-dominant decision area in both countries. It must be mentioned here that husband- or wife-dominant purchasing decisions are related to product class and/or form. Even within a product class/form husbanddominant decision situation, the wife may make decisions on the product 
Figure 2: Decision making for different product categories in general

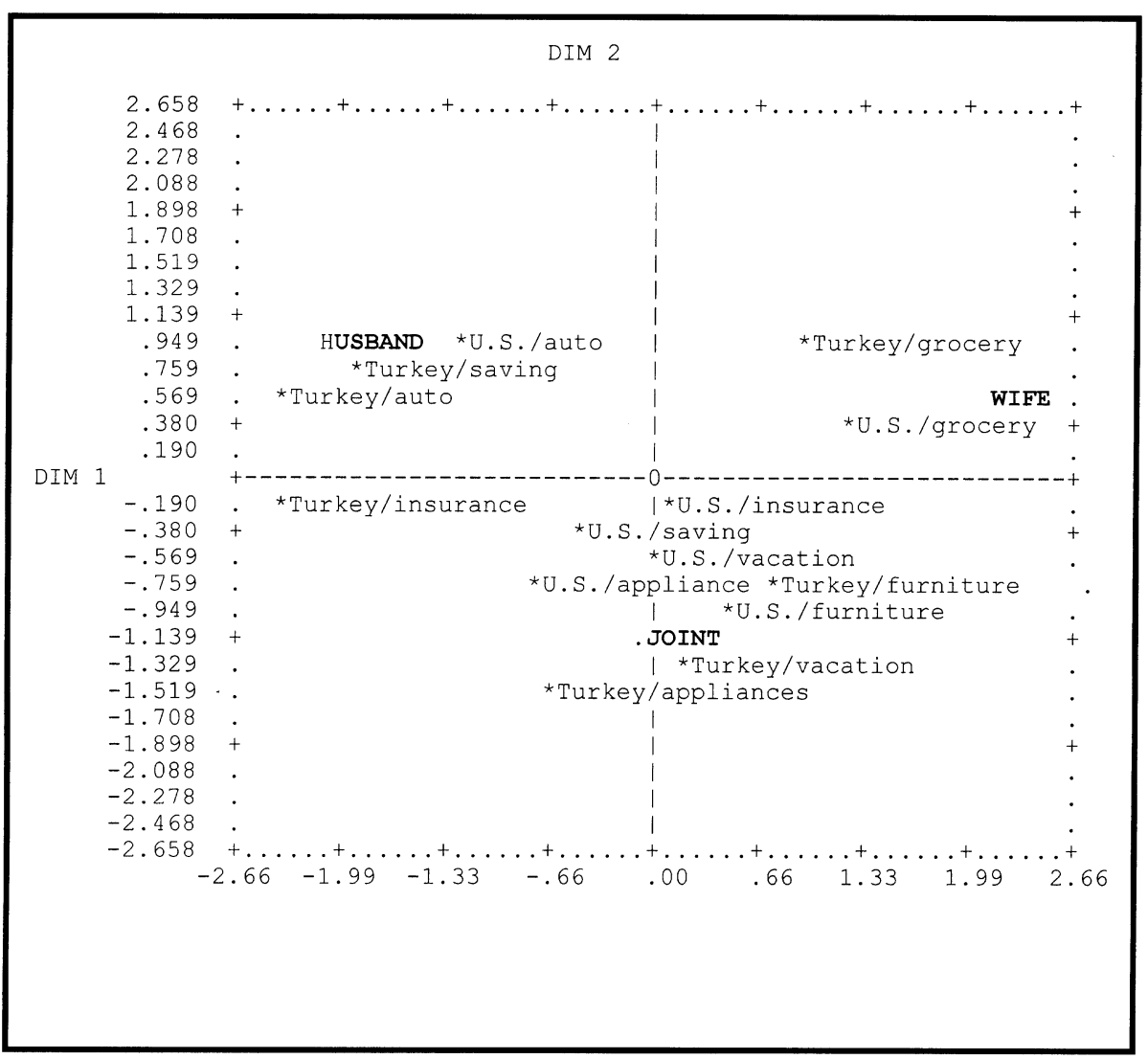

brand and/or options. Automobile purchase decision is the case in point here. In both countries, during automobile purchases, while husbands make a decision on the engine capacity, mainframe and speed, wives present input on styling, colour and interior design. In decision-making situations, husband and wife influences are, in most cases, mixed and of relative importance; each varies from product to product. Insurance purchases and savings account opening decisions are reported to be husbanddominant decision areas in Turkey. The reason for this is that in Turkey, in most cases, husbands are the breadwinners.

The vertical axis represents the joint decision-making dimension of the relationship. This axis explains the remaining 42.7 per cent of the total 
Figure 3: When-to-buy comparison of different product categories

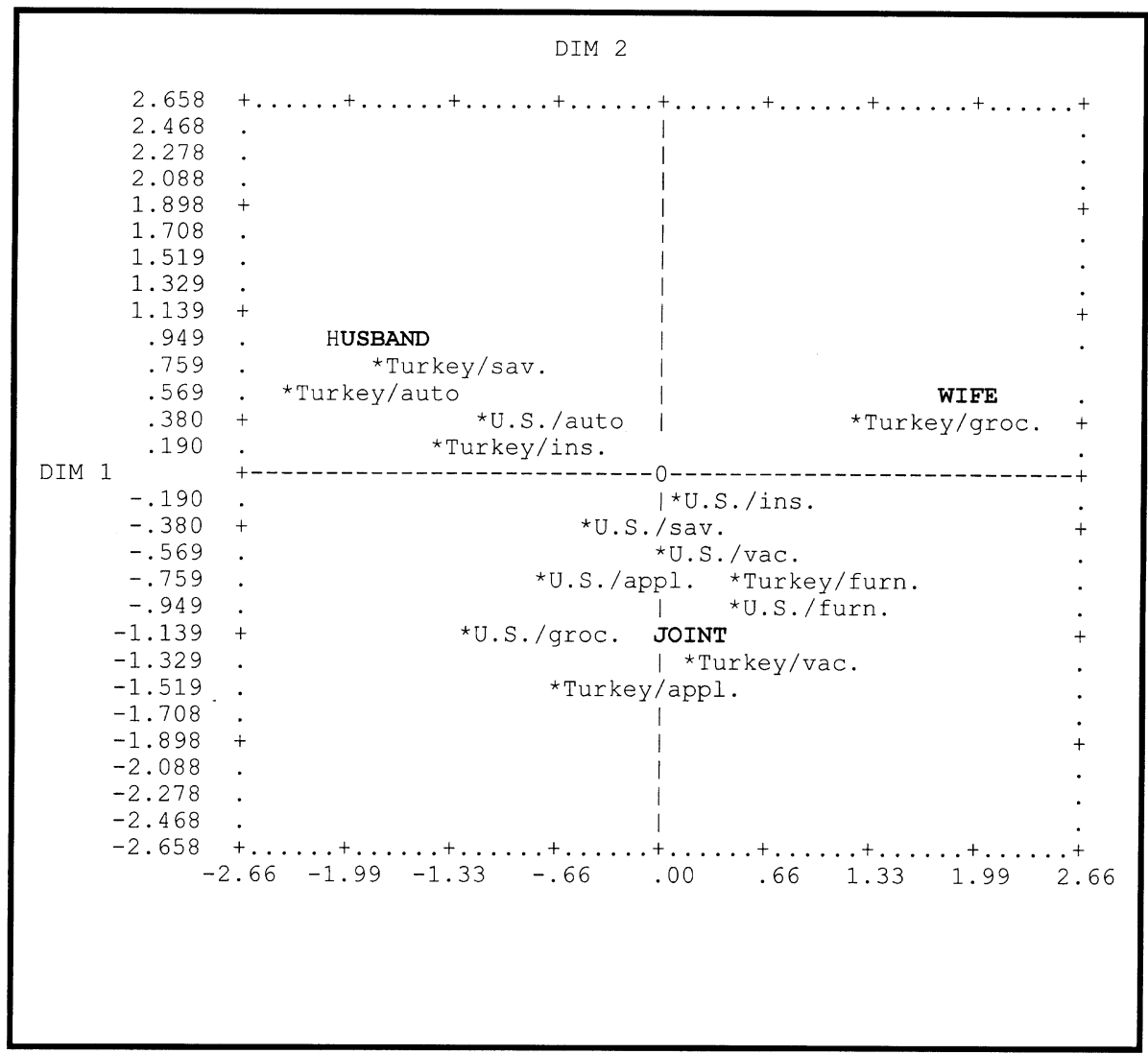

variation. An examination of the graph reveals that furniture, vacation selection and appliance purchase decisions are reportedly made by husband and wife jointly. As indicated previously, while insurance and saving decisions seem to be dominated by the husbands in Turkey, these decisions are made jointly in the USA.

Figures 3 to 6 show the results of the correspondence analysis as to when, where, what and how much comparison was made of different product categories. Figure 3 depicts the findings regarding when the decisions are made. While savings and insurance decisions seem to be husband dominant in Turkey, they are jointly made in the USA. Decisions regarding when to buy automobiles are made by husbands in both countries. The wife is the decision maker while buying 
Figure 4: Where-to-buy comparison of different product categories

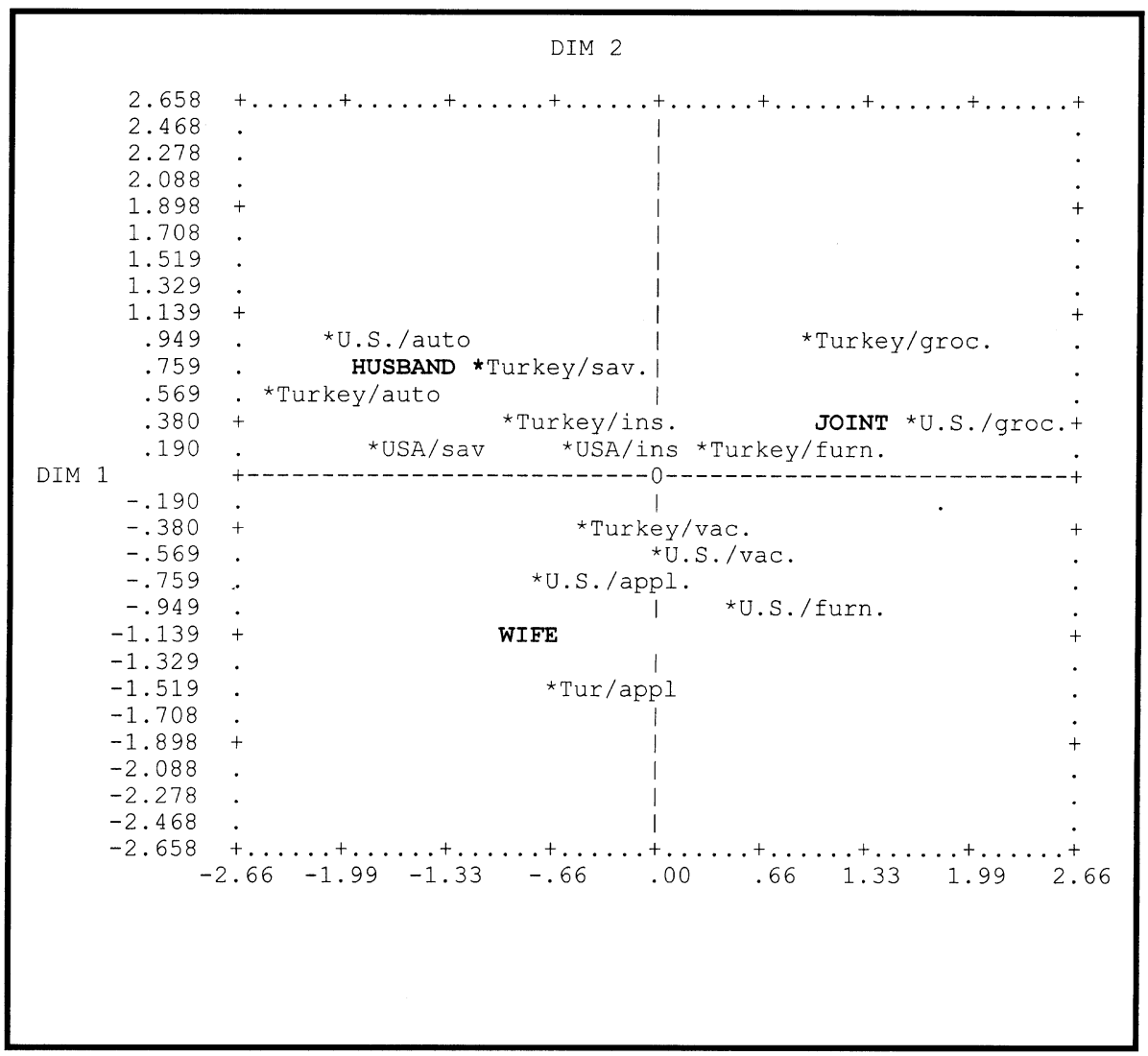

groceries in Turkey, but this is a joint decision-making process in the USA. Buying furniture and appliances and vacation selection decisions are made jointly in both countries. Figure 4 presents the findings of where-to-buy decisions. The husband is the decision-maker in both countries as to automobile purchases and savings decisions. While insurance purchase decisions are mainly made by husbands in
Turkey, these decisions are made jointly in the USA. In both countries, husband and wife jointly determine where to buy groceries. While the furniture purchase decisions are made by the wife in the USA, both husband and wife are involved in these decisions in Turkey. Appliance and vacation purchase decisions are made by wives in both countries. Figure 5 depicts the results of which-products- 
Figure 5: What-to-buy decisions for the product categories

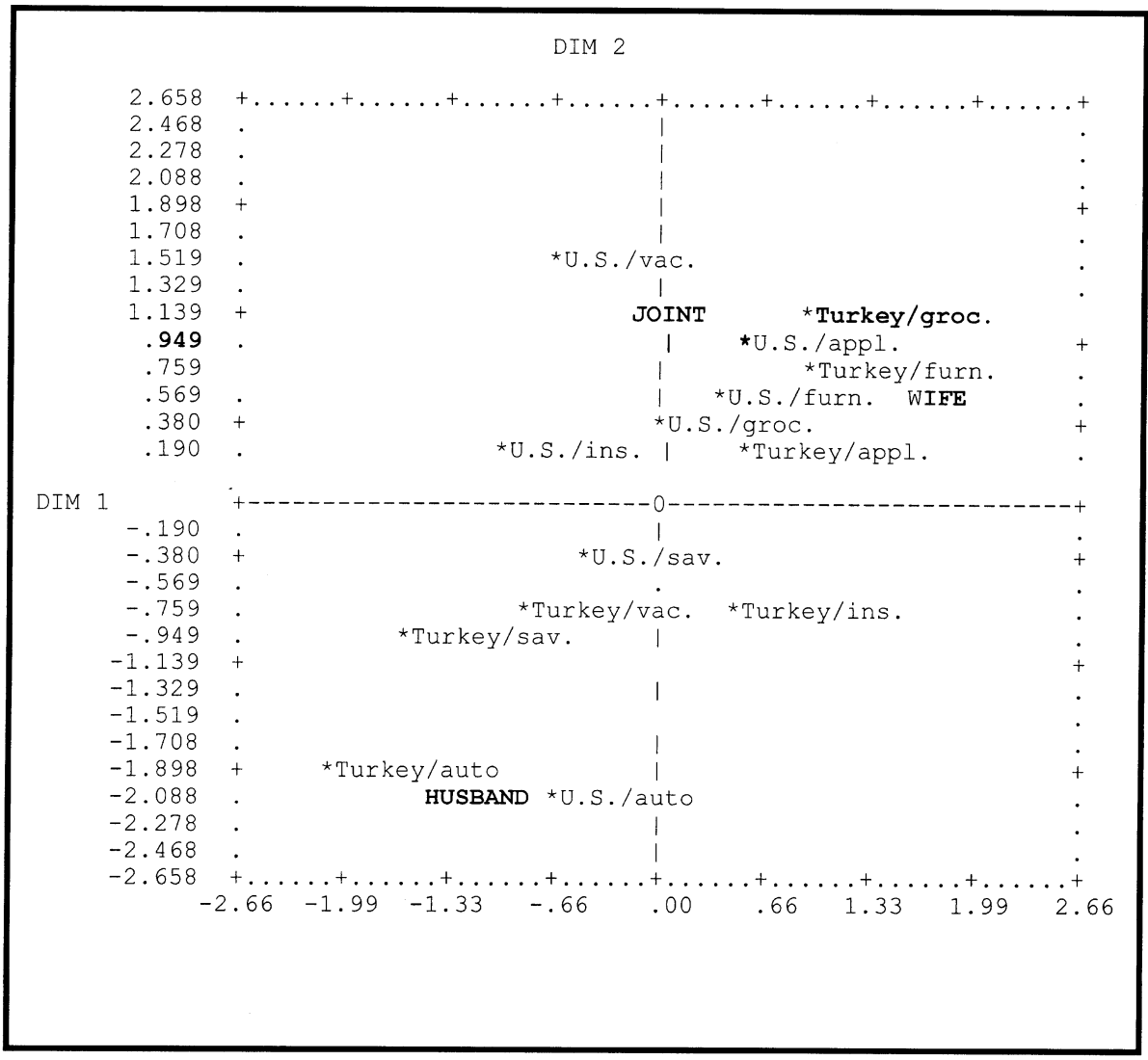

to-buy decisions. While the vacation destination selection decisions are made by the husband in Turkey, in the USA this is a joint decision. In both countries, automobile and savings decisions are made by husbands. On the other hand, wives make grocery, furniture and appliance purchase decisions. Figure 6 shows the how-muchto-pay decision results. While husbands make insurance and automobile decisions, wives in both countries make the grocery decisions. The husband is the decision-maker in Turkey as to savings; in the USA this is a joint decision.

\section{CONCLUSIONS}

This empirical study shows a surprisingly high degree of cross-cultural 
Figure 6: How-much-to-pay decisions for different product categories

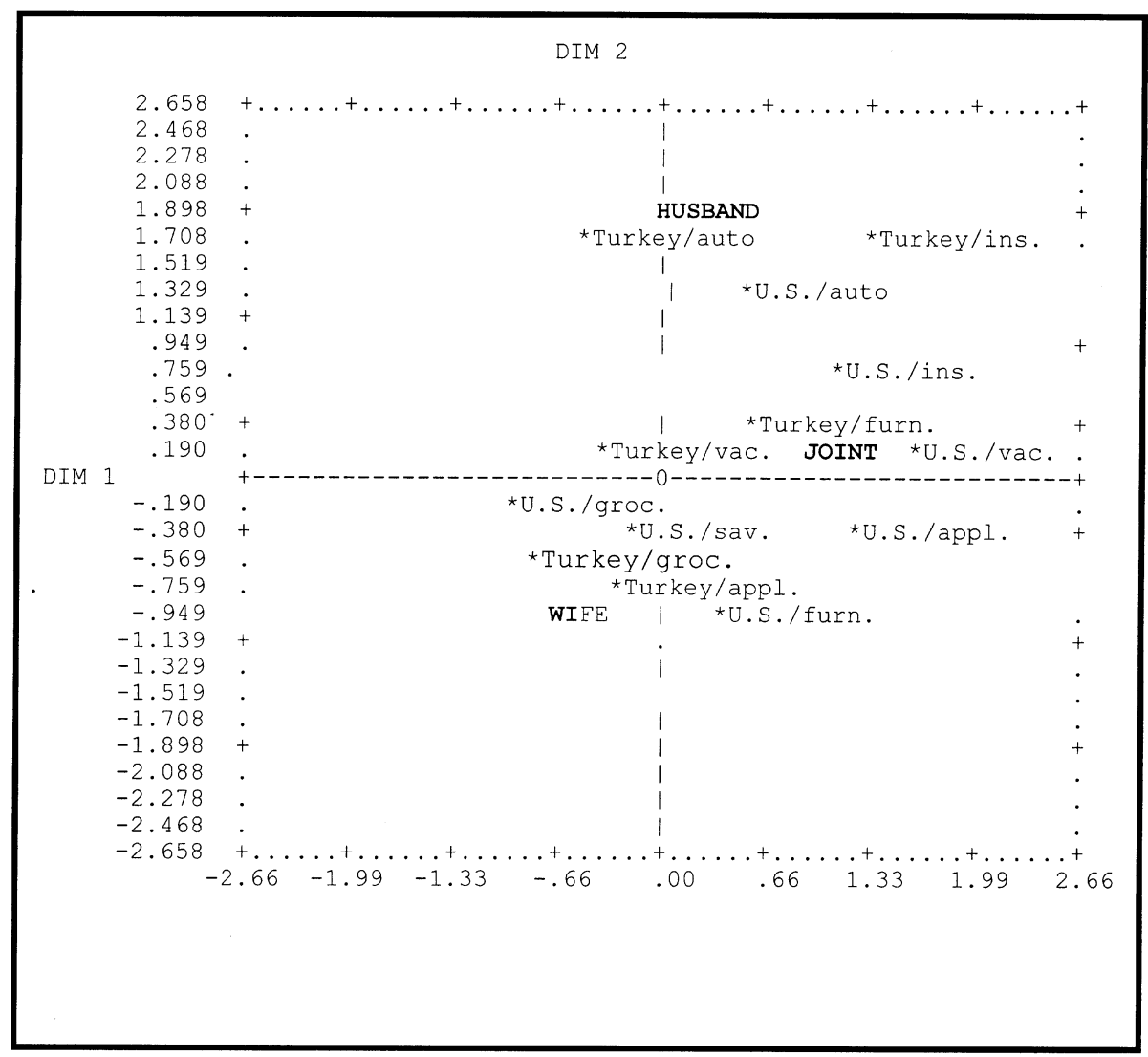

similarity in family decision-making roles between the two countries. Although, expectedly so, the husband plays a more dominant role in the purchase of most of the selected products in Turkey, there are some products and services for which no differences exist between husbands' decision making in the USA and Turkey. While the present study should be considered exploratory, the findings can be considered illustrative of the types of similarities and/or differences that might be found in family decision making and buying patterns across distinct cultures. Hence, international marketers should study those differences in family buying roles, which may exist in other countries than the home country to which they are 
accustomed, especially countries which possess vastly different social, behavioural, cultural and economic conditions.

In the light of the pronounced similarities and differences, appropriate target marketing strategies need to be found. In cases of distinct similarities between the two countries, standardised marketing strategies may be used where identical advertising copy and thrust will be put in place.

\section{REFERENCES}

1 Blood, R. O. and Wolfe, D. M. (1960) 'Husbands and wives', Free Press, Glencoe, IL.

2 Burgess, E. W. and Locke, H. J. (1960) 'The family: From institution to companionship', 2nd ed., American Book Co., New York.

3 Cox, E. P. (1975) 'Family purchase decision making and process of adjustment,' Journal of Marketing Research, Vol. 12, pp. 189-195.

4 Davis, H. L. (1970) 'Dimensions of marital roles in consumer decision making, Journal of Marketing Research, Vol. 7, No. 2, pp. 168-177.

5 Davis, H. L. (1976) 'Decisionmaking within the household,' Journal of Consumer Research, Vol. 2, pp. 241-260.

6 Davis, H. L. and Rigaux, B. P. (1974) 'Perception of marital roles in decision process,' Journal of Consumer Research, Vol. 1, pp. 51-62.

7 Ferber, R. and Nicosia, F. (1972) 'Newly married couples and their asset accumulation decisions, in Strumpel, B., Morgan, J. N. and Zahn, E. (eds),
'Human behavior in economic affairs: essays in honor of George Katona', Elsevier, San Francisco: Josey-Bass; Amsterdam, pp. 161-187.

8 Wolgast, E. H. (1958) 'Do husbands or wives make the purchasing decisions?' Journal of Marketing, Vol. 23, pp. 151158.

9 Holman, C. R. and Hendrich, H. W. (1973) 'Effects of status and individual ability on group problem solving,' Decision Sciences, Vol. 4, pp. 55-63.

10 Ferber, R. (1973) 'Family decision making and economic behavior', in Sheldon, E. B. (ed.) 'Family and economic behavior: Problems and prospects', J. B. Lippincott Co., Philadelphia.

11 Agrawal, J. and Kamakura, W. A. (1999) 'Country-of-origin: A competitive advantage?', International Journal of Research in Marketing, Vol. 16, No. 4, December, pp. 255-267.

12 Verlegh, P. W. J. and Steenkamp, J. B. E. M. (1999) 'A review and metaanalysis of country-of-origin research,' Journal of Economic Psychology, Vol. 20, pp. 521-546.

13 Peterson, R. A. and Jolibert, A. J. P, (1995) 'A meta-analysis of country-oforigin effects,' Journal of International Business Studies, Vol. 26, No. 4, pp. 883-899.

14 Davis (1976) op. cit.

15 Burns, A. C. and Granbolis, D. H. (1979) 'Advancing the study of family purchase decision making,' Advances in Consumer Research, Vol. 7, pp. 221226.

16 Burns, A. C. and Ortinau, D. (1978) 'Underlying perceptual patterns in 
husband and wife purchase decision influence assessments,' Advances in Consumer Research, Vol. 6, pp. 372-376.

17 Jenkins, R. L. (1979) 'Contributions of theory to the study of consumer decision-making,' Advances in Consumer Research, Vol. 7, pp. 207-211.

18 Sproles, G. B. (1985) 'From perfectionism to faddism: Measuring consumers' decision making styles', Proceedings of American Council on Consumer Interest Conference, Columbia, pp. $79-85$.

19 Sproles, G. B. and Kendall, E. L. (1986) 'A methodology for profiling consumers' decision-making styles,' Journal of Consumer Affairs, Vol. 20, No. 2, Summer, pp. 267-279.

20 Sproles, E. K. and Sproles, G. B. (1990) 'Consumer decision making styles as a function of individual learning styles', The Journal of Consumer Affairs, Vol. 24, Summer, pp. 134-147.

21 Mitchell, V. M. and Bates, L. (1998) 'U.K consumer decision making styles,' Journal of Marketing Management, Vol. 14, pp. 199-225.

22 Mowen, J. C. (1988) 'Beyond consumer decision making, Journal of Consumer Marketing, Vol. 5, No. 1, Winter, pp. 15-25.

23 Hafstrom, J. L. (1992) 'Consumer decision-making styles: Comparison between United States and Korean young consumers,' Journal of Consumer Affairs, Vol. 26, No. 1, Summer, pp. 146-158.

24 McDonald, William J. (1995) 'American versus Japanese consumer decision-making: An exploratory cross-cultural content analysis', Journal of International Consumer Marketing, Vol. 7, No. 3, pp. 81-93.

25 Hafstrom (1992) op. cit.

26 Fan, J. X. (1998) 'Consumer decisionmaking styles of young-adult Chinese, Journal of Consumer Affairs, Vol. 32, No. 2, Winter, pp. 275-294.

27 Krampf, R. F. (1993) 'Consumer decision making and the nature of the product: A comparison of husband and wife adoption process location,' Psychology and Marketing, Vol. 10, No. 2, March/April, pp. 95-109.

28 Mohan, M. (1995) 'The influence of marital roles in consumer decision making,' Irish Marketing Review, Vol. 8, pp. 97-106.

29 Menasco, M. B. and Cury, D. J. (1989) 'Utility and choice: An empirical study of wife/husband decision making,' Journal of Consumer Research, Vol. 16, pp. 87-97.

30 Green, R. T. and Cunningham, I. C. (1980) 'Family purchasing roles in two countries,' Journal of International Business Studies, Vol. 11, pp. 92-97.

31 Davis and Rigaux (1974) op. cit.

32 Green and Cunningham (1980) op. cit.

33 Green, R. T., Leonardi, J-P., Chandom, J-L., Cunningham, I. C. M., Verhage, B. and Strazzieri, A. (1983) 'Societal development and family purchasing roles: A cross-national study, Journal of Consumer Research, Vol. 9, pp. 436-442.

34 Hempel, D. (1974) 'Family buying decisions: A cross-cultural perspective,' Journal of Marketing Research, Vol. 11, pp. 295-302.

35 Green et al. (1983) op. cit.

36 Davis and Rigaux (1974) op. cit.

37 Green et al. (1983) op. cit. 
38 Yavas, U., Babakus, E. and Delener, N. (1994) 'Family purchasing roles in Saudi Arabia: Perspective from Saudi wives,' Journal of Business Research, Vol. 31, pp. 75-86.

39 Wells, W. D.(1975) 'Psychographics: A critical review, Journal of Marketing Research, Vol. 12, May, pp. 196-213.

40 Wells, W. and Tigert, D. (1977) 'Activities, interests, and opinions,' Journal of Advertising Research, Vol. 11, No. 4, pp. 27-35.

41 Mitchell, A. (1993) 'The nine American life-styles', MacMillan Publishing Company, New York..

42 Anderson, W.T. and Golden, L. (1984) 'Life-style and psychographics: A critical review and recommendation, in Kinnear, T. (ed.) 'Advances in consumer research, XI', Association for Consumer Research, Ann Arbor, Michigan, pp. 405-411.
43 Davis and Rigaux (1974) op. cit.

44 Shimp, T. A. and Subhash, S. (1987) 'Consumer ethnocentrism: Construction and validation of the CETSCALE', Journal of Marketing Research, Vol. 24, August, pp. 280-289.

45 Brislin, R. and Baumgardner, S. (1971) 'Non random sampling of individuals in cross-cultural research,' Journal of Cross-Cultural Psychology, Vol. 2, pp. 397-400.

46 Berry, J. (1969) 'On cross-cultural comparability, International Journal of Psychology, Vol. 4, pp. 119-128.

47 Greenacre, M. J. (1984) 'Theory and applications of correspondence analysis', Academic Press, London.

48 Greenacre, M. J. (1989) 'The geometric interpretation of correspondence approach,' Journal of the American Statistical Association, Vol. 82, pp. 437-447. 